Article - Agriculture, Agribusiness and Biotechnology

\title{
Population Changes of Eubacteria, Sulfate-Reducing Bacteria and Methanogenic Archaea in an Anaerobic Reactor Processing Ethanol Distillery Vinasse
}

\author{
Adis Ivonne Terry Brown ${ }^{1}$ \\ https://orcid.org/0000-0001-6852-9777 \\ Eloisa Pozzi ${ }^{1^{*}}$ \\ https://orcid.org/0000-0002-6631-8295 \\ Marcia Helena Rissato Zamariolli Damianovic ${ }^{1}$ \\ https://orcid.org/0000-0001-7738-3722
}

Homero Enrique Urrutia Briones ${ }^{2}$

https://orcid.org/0000-0001-8895-5933

\section{Leslie Ester Abarzúa Ortiz ${ }^{2}$}

\section{Eduardo Cleto Pires ${ }^{1}$}

https://orcid.org/0000-0001-6943-3988

${ }^{1}$ University of São Paulo, Engineering School of São Carlos, Laboratory of Process Biological, São Carlos, SP, Brazil, ${ }^{2}$ University of Concepcion, Biotechnology Center, Laboratory of Biofilms and Environmental Microbiology, Concepcion, Chile.

Received: 2018.05.28; Accepted: 2019.03.26.

*Correspondence: elopozzi@sc.usp.br; Tel.: +551633738357

\section{HIGHLIGHTS}

- UASB reactors are widely used in vinasse wastewater.

- Archaea, Bacteria Domain and sulfate-reducing bacteria.

- Population differences were found by DGGE technique.

- PCRq was effective in the quantitative differentiation among populations. 
Abstract: The microbiological characterization by molecular techniques (DGGE and quantitative PCR) of Archaea, Bacteria domain and sulfate-reducing bacteria (SRB) from a laboratory scale Up-flow Anaerobic Sludge Blanket (UASB) processing sugar cane vinasse was performed during the operational phase with increasing organic loads. The organic load removal efficiency was between $97 \%$ and $75 \%$ for volumetric organic loads (VOL) in the range of 0.6 to $15.4 \mathrm{kgCOD} \cdot \mathrm{m}^{-3} \cdot \mathrm{d}^{-1}$ and for higher VOL (until $27.0 \mathrm{kgCOD} \cdot \mathrm{m}^{-3} \cdot \mathrm{d}^{-1}$ ) the removal efficiency decreased to $48 \%$. Archaea represented the majority of the estimated population $\left(10^{7}\right.$ copies of $16 \mathrm{~S}$ RNA ribosomal gene. $\left.\mathrm{mL}^{-1}\right)$ followed by bacteria $\left(10^{6}\right.$ copies of 16S RNA ribosomal gene. $\left.\mathrm{mL}^{-1}\right)$ and sulfate-reducing bacteria (SRB) $\left(10^{5}\right.$ copies of dsrB gene. $\mathrm{mL}^{-1}$ ). There was a significant difference between the populations of Archaea and SRB with increasing VOL. DGGE profiles show differences among populations with increasing VOL, especially with respect to sulfate-reducing bacteria. The presence of SRB together with a high sulfate removal percentage $(97 \%)$ of about $15 \mathrm{kgCOD} \cdot \mathrm{m}^{-3} \mathrm{~d}^{-1 \mathrm{~h}}$, indicates the establishment of a sulfidogenic process.

Keywords: UASB reactor, microbial characterization, Methanogenesis, Sulfidogenesis, DGGE, quantitative PCR.

\section{INTRODUCTION}

The success of any anaerobic process depends greatly on the permanence of adapted, stress resistant biomass with high microbial activity in the reactors. UASB (Up-flow Anaerobic Sludge Blanket) reactors are widely used in vinasse wastewater treatment [1-2]. In UASB-type reactors the active granulated biomass is considered as the major reason for the success of industrial effluent treatments and this reactor operates at relative low hydraulic retention time and biogas production favoring contact with microorganisms. The quality of the treatment system is directly related to the stability of the sludge, which is vitally important for processing complex effluents, such as distillery vinasse.

Ethanol distillery vinasse is characterized as a dark brown liquid waste with organic matter concentration measured as chemical oxygen demand (COD) that can be higher than $100 \mathrm{~g} . \mathrm{L}^{-1}$ and having $\mathrm{pH}$ between 3.5 and 5 [3-4]. Because it is rich in inorganic constituent, mainly calcium and potassium, it is applied to the soil as a biofertilizer. However, this wastewater also contains phytotoxic, recalcitrant compounds such as phenols, polyphenols and heavy metals that can cause deleterious effects to soil microfauna and plants besides groundwater contamination [3].

Contamination of the industrial fermentation of sugarcane juice by bacteria and also by spurious yeast strains is controlled by acid treatment, generating sulfate-rich acidic wastewater [5]. In anaerobic reactors, sulfate-reducing bacteria (SRB), mainly in substrates such as vinasse that is rich in sulfate, compete with the methanogenic and acetogenic microorganisms for the same substrate. Hydrogenotrophic SRB obtains more energy relative to molecular hydrogen such as hydrogenotrophic methanogenic archaea (HMA) that have a greater affinity for hydrogen. This causes the concentration of bioavailable hydrogen to decrease for such archaea. This explains the rapid inhibition of HMA when sulfate ions feed the anaerobic reactor. SRB also compete with acetoclastic methane archaea (AMA) for acetic acid. In addition, they may compete for hydrogen and sodium formate, which is an intermediate in the process of anaerobic degradation with syntrophic acetogenic bacteria [6] and also by acetic acid [7-8].

The correlations between microbial diversity and operational aspects to obtain additional information on the performance of the reactor can provide tools to better design treatment processes.

In this study we used Denaturing Gel Gradient Electrophoresis (DGGE) molecular techniques with the aim of monitoring changes in microbial communities of Archaea and Bacteria in a UASB reactor on a laboratory scale fed with increasing organic loads of vinasse from a sugar cane ethanol distillery. 
In addition, population estimates of Archaea, Bacteria and Sulfate Reducing Bacteria (SRB) by Polymerase Chain Reaction (PCR) in real time (quantitative) allowed comparisons among them and inferences about the possible removal efficiency variations.

The importance of this study is the use of techniques of molecular biology to characterize the main microbial groups responsible for anaerobic digestion in UASB reactors fed with vinasse and to relate them to the performance of the reactor subject to the increase of volumetric organic loads.

\section{MATERIAL AND METHODS}

\section{Wastewater and inoculum}

During the experimental tests, the wastewater used was vinasse, the distillate product of the fermented sucrose broth for ethanol production, provided by a vinasse distillery plant in São Paulo state, Brazil. The low concentrations of the vinasse used to feed the reactor were obtained by dilution with tap water with $\mathrm{NaHCO}_{3}$, depending on the desired concentration.

The inoculum used was granular sludge from a UASB reactor, treating wastewater from a poultry slaughterhouse [9] and was adapted to the vinasse from a prototype methanogenic UASB reactor in continuous operation with low loads of ethanol distillery vinasse.

\section{Experimental apparatus and operational conditions}

A laboratory scale anaerobic reactor was used based on the design adopted by UASB type reactors with a total operating capacity of 20 liters. The reactor is of approximately 10 $\mathrm{cm}$ diameter and total height of $200 \mathrm{~cm}$. The bottom half, which is for the reaction chamber, has a $10 \mathrm{~L}$ capacity. The upper part, with $10 \mathrm{~L}$ volume capacity is used as a separator (sedimentation and separation of biogas). Although built as a one piece reactor due to its aspect ratio (1:20) for performance assessment, it can be considered as a reactor and a sedimentation chamber assembled in series. The gas outlet is at the top part. The reactor was fed with the vinasse diluted with the reactor effluent. During the operation period, the operational parameters were: up flow velocity equal to $0.13 \mathrm{~m} \cdot \mathrm{h}^{-1}$, temperature equal to $30^{\circ} \mathrm{C} \pm 1^{\circ} \mathrm{C}$; feed flow rate equal to $23.6 \mathrm{~L} . \mathrm{d}^{-1}$. The feed was continuously kept by a peristaltic pump (Prominent Dosiertechnik). The volume of added vinasse varied from $100 \mathrm{~mL}$ at the beginning of the operational period to $3.6 \mathrm{~L}$ at the end of the period, with a gradual increase of COD affluent from 1000 to $20700 \mathrm{mg} \cdot \mathrm{L}^{-1}$ (volumetric organic load from 0.63 to $24.3 \mathrm{~kg}$ COD. $\mathrm{m}^{-3} \cdot \mathrm{d}^{-1}$, respectively). The load was increased whenever the system had COD removal efficiency greater than or equal to $70 \%$. The experimental phase lasted 202 days/operation and 52 hours hydraulic retention time (HRT) was maintained.

The conversion potential of the organic matter in methane was estimated for the inoculum and during the period of operation with VOCs between $3-4 \mathrm{Kg} \mathrm{COD} \cdot \mathrm{m}^{-3} \cdot \mathrm{d}^{-1}$ (86 days of operation) in batch experiments and calculating the specific methanogenic activity (SMA) using carbon sources of sodium acetate and sodium formate (20 and $10 \mathrm{mM}$, respectively)[10].

\section{Operational and performance parameters}

The organic volumetric load was calculated by equation (1):

$$
\mathrm{VOL}=\left(\mathrm{Q}^{*} \mathrm{COD}_{\text {influ }}+5.5{ }^{*} \mathrm{COD}_{\text {efflux }}\right) / \mathrm{V}_{\mathrm{r}}
$$


Where: VOL is volumetric organic loading; CODefflu is the effluent concentration; CODinflu is the vinasse concentration; $\mathrm{Vr}$ is the volume of reactor and $\mathrm{Q}$ the vinasse flow rate.

The organic load (OL) removal efficiency was evaluated by equation (2):

$$
\eta_{R}=(O L)-\left(Q^{*} C_{\text {efflux }}\right) /(O L)
$$

\section{Analytical methods}

Physico-chemical analyses were performed of glass fiber filtered samples ( $45 \mu \mathrm{m}$ of porosity): soluble chemical oxygen demand (sCOD) and $\mathrm{pH}$ of the influent and effluent according to Standard Methods [11].The volatile fatty acids (VFA) were quantified by gas chromatography (GC201, Shimadzu) equipped with a flame ionization detector and INOWAX column, $30 \mathrm{~m}^{\star} 25 \mathrm{~mm}^{*} 0.25 \mu \mathrm{m}$ [12]. Sulfate was measured by lon Chromatographic Method using a chromatograph model Dionex ICS 5000® equipped with a chemical conductivity suppressor. Sample preparation consisted of only a filtration (1.2- $\mu \mathrm{m}$ glass fibre membrane followed by $0.22 \mu \mathrm{m}$ cellulose acetate membrane) and sample dilution. Calibration curves were linear and well-adjusted between 2.5 and $50 \mathrm{mg} . \mathrm{L}^{-1}$. The column temperature was set at $35^{\circ} \mathrm{C}$, and the conductivity detector was $30^{\circ} \mathrm{C}$. Injection was made through an AS auto-sampler device, and the injection loop volume was set at $10 \mu \mathrm{L}$. All parts of the IC, such as the injection valve, high-pressure pump, conductivity detector, suppressor module, peristaltic pump and auto-sampler were fully controlled by the Chromeleon Chromatography Management, 7.1 program. Isocratic elution (at a flow rate of $1.0 \mathrm{~mL}$. $\mathrm{min}^{-1}$ ) was used, and an analytical grade (> 99\%) sodium carbonate (Aldrich) and sodium hydrogen carbonate (Sigma-Aldrich_Steinheim, Germany) were diluted in ultra-purified water to prepare the eluent at a concentration of 4.5 and $0.8 \mathrm{mM}$, respectively [13]. Sulfide concentration was determined by the colorimetric method on HACH DR-2800 ® spectrophotometers using a Sulfide Analysis Kit (Reagents Code 1816-32 and 1877-32).

\section{Microbiological tests}

The samples for the molecular analyses were taken from the sludge of the reactor bed at VOL of $6.75 \mathrm{~kg}$ COD. $\mathrm{m}^{-3} \cdot \mathrm{d}^{-1}, 15.44 \mathrm{~kg}$ COD. $\mathrm{m}^{-3} \cdot \mathrm{d}^{-1}$ and $24.31 \mathrm{~kg}$ COD. $\mathrm{m}^{-3} \cdot \mathrm{d}^{-1}$. Extraction of genomic DNA [14] from sludge and PCR were done for the analysis of DGGE [15] and qPCR [16].

The microbiota of the Archaea Domain was characterized by the set of primers 1100FGC and 1400R [17]. For the Bacteria Domain, the set of primers 968FGC and 1392R [18] was used, both for 16S RNA ribosomal. For the sulfate reducing bacteria (SRB), a pair of specific primers (DSRp2060F and DSR4R) was used for amplifying the dsrB gene fragments [19].The dendrograms of the band profiles, obtained from DGGE gel images, were constructed by the Bionumerics ${ }^{\circledR}$ program (version 3.5 ) using the unweighted pair group method with arithmetic average (UPMA) method. A matrix of similarities was calculated based on the Pearson correlation.

The relative quantification of organisms by real-time PCR (qPCR) was done using the fluorophore SYBR $\AA$ Green [20] in a thermocycler (Roche $\AA$ Light Cycler 2.0) at the Laboratory of Biofilms and Environmental Microbiology, Biotechnology Center, University of Concepcion, Chile.

The 787F and 1387R primers were used for the Bacteria Domain (amplification of the 16S rRNA gene) [21] for the analysis of qPCR. The 344F and 915R primers were used for the Archaea Domain (16S rRNA gene) [22]. The DSRp2060F and DSR4R primers were used for the SRB [10]. For the melt curve analysis, the temperature was increased at a rate 
of $0.1^{\circ} \mathrm{C} . \mathrm{s}^{-1}$ increments from 65 to $95^{\circ} \mathrm{C}$. Threshold cycle (Ct) values were automatically calculated by the Light Cycler software 4.05. Calibration curves were constructed from serial decimal dilutions $\left(10^{10}\right.$ to $\left.10^{\circ}\right)$ from pure cultures of Listeria mocitogenes (ATCC 1915) (Bacteria Domain), Methanosarcina mazei (ATCC BAA-159D) (Archaea Domain) and SRB isolated from environmental samples at the institution's research laboratory in Chile. The number of copies of the $16 \mathrm{~S}$ rRNA gene and dsrB gene (number of cells) from the DNA concentration in $\mathrm{ng} / \mu \mathrm{L}$ was calculated [23]. The comparison of results for the density of the three groups of microorganisms, obtained by qPCR and related to the different VOL followed the analysis of variance (ANOVA, significance level of 5\%) [24].

\section{RESULTS}

The characterization of raw vinasse is shown in Table 1. Volumetric organic load (VOL), organic load removal efficiency $(\eta)$ and VOL removed from the sludge blanket is shown in Table 2.

Table 1. Mean values of raw vinasse characterization [26]

\begin{tabular}{|c|c|}
\hline Parameter & Concentration $\left(\mathrm{g} . \mathrm{L}^{-1}\right)$ \\
\hline Electrical conductivity $\left(\mathrm{mS} \mathrm{cm}^{-1}\right)$ & 5.15 \\
\hline COD Total & $27.8 \pm 4.08$ \\
\hline COD Soluble & $24.5 \pm 4.16$ \\
\hline Total solids & $30.8 \pm 4.21$ \\
\hline Total volatile solids & $20.9 \pm 2.42$ \\
\hline Volatile suspended solids & $1.62 \pm 1.01$ \\
\hline Total volatile fatty acids & $1.31 \pm 0.41$ \\
\hline Total nitrogen & $0.244 \pm 0.02$ \\
\hline $\mathrm{P}-\mathrm{PO}_{4}^{3+}$ & $0.092 \pm 0.03$ \\
\hline Carbohydrates & $4.5 \pm 1.04$ \\
\hline $\mathrm{Na}^{+}$ & $3.82 \pm 0.71$ \\
\hline $\mathrm{K}^{+}$ & $3.67 \pm 0.75$ \\
\hline $\mathrm{Mg}^{2+}$ & $0.346 \pm 0.13$ \\
\hline $\mathrm{Ca}^{2+}$ & $0.430 \pm 0.18$ \\
\hline $\mathrm{SO}_{4}{ }^{2-}$ & $1.41 \pm 0.49$ \\
\hline $\mathrm{Cl}^{-}$ & $1.62 \pm 0.56$ \\
\hline
\end{tabular}


Table 2. Volumetric organic load (VOL), organic load removal efficiency $(\eta)$ and VOL removed from the sludge blanket.

\begin{tabular}{|c|c|c|}
\hline $\begin{array}{c}\text { VOL applied } \\
\left(\mathrm{kgCOD} \cdot \mathrm{m}^{-3} \cdot \mathrm{d}^{-1}\right)\end{array}$ & $\begin{array}{c}n \\
(\%)\end{array}$ & $\begin{array}{l}\text { VOL removed in the sludge } \\
\text { blanket } \\
\left(\mathrm{kgCOD} \cdot \mathrm{m}^{-3} \cdot \mathrm{d}^{-1}\right)\end{array}$ \\
\hline 0.63 & 93.2 & 0.59 \\
\hline 0.87 & 89.6 & 0.78 \\
\hline 1.18 & 97.2 & 1.15 \\
\hline 1.34 & 97.3 & 1.30 \\
\hline 2.54 & 96.0 & 2.44 \\
\hline 2.80 & 96.1 & 2.69 \\
\hline 3.17 & 95.2 & 3.02 \\
\hline 3.57 & 95.7 & 3.42 \\
\hline 3.64 & 93.0 & 3.38 \\
\hline 4.27 & 95.0 & 4.06 \\
\hline 6.75 & 91.0 & 6.14 \\
\hline 10.25 & 85.1 & 8.72 \\
\hline 13.73 & 75.1 & 10.31 \\
\hline 15.44 & 75.3 & 11.62 \\
\hline 24.49 & 56.1 & 13.73 \\
\hline 24.31 & 59.3 & 14.42 \\
\hline 27.01 & 48.9 & 13.20 \\
\hline
\end{tabular}

Estimation of microbial density by quantitative PCR in different VOL for Bacteria, Archaea and sulfate-reducing bacteria is shown in Figure 1.

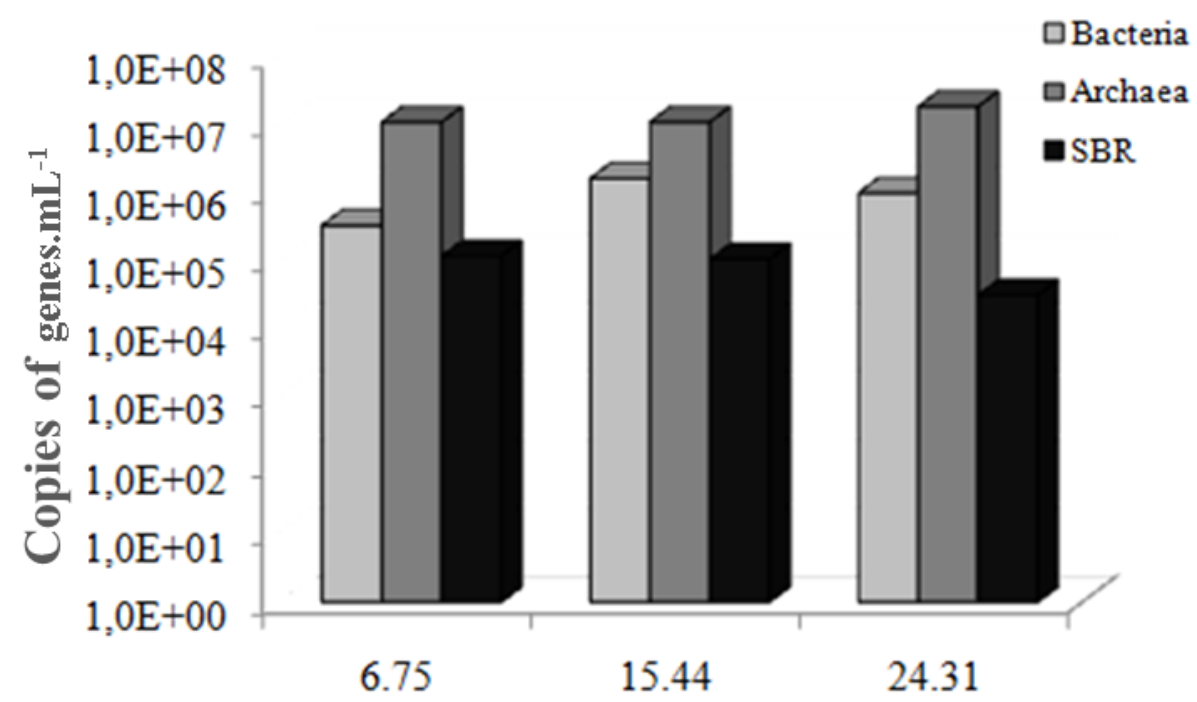

Figure 1. Estimation of microbial density (qPCR) in different VOL for Bacteria, Archaea and SRB. 
DGGE profiles band of Archaea, Bacteria and sulfate-reducing bacteria and similarity coefficient in percentage (Pearson correlation) for different volumetric organic load are shown in Figure 1, Figure 2 and Figure 3, respectively.

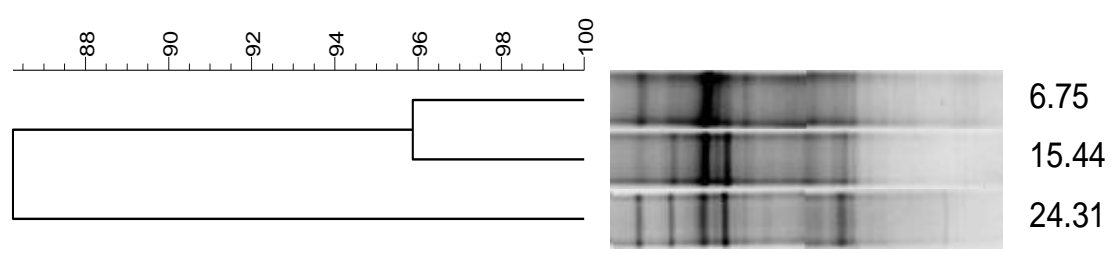

Figure 2. Dendrogram (UPMA) of the band profiles of the Archaea and their similarity coefficient in percentage (Pearson correlation [0.0\%-100.0\%]) for sludge blanket to VOL of $6.75 \mathrm{~kg} \mathrm{COD} . \mathrm{m}^{-3} \cdot \mathrm{d}^{-1}$; VOL of $15.44 \mathrm{~kg}$ COD. $\mathrm{m}^{-3} \cdot \mathrm{d}^{-1}$ and VOL of $24.3 \mathrm{~kg}$ COD. $\mathrm{m}^{-3} \cdot \mathrm{d}^{-1}$.

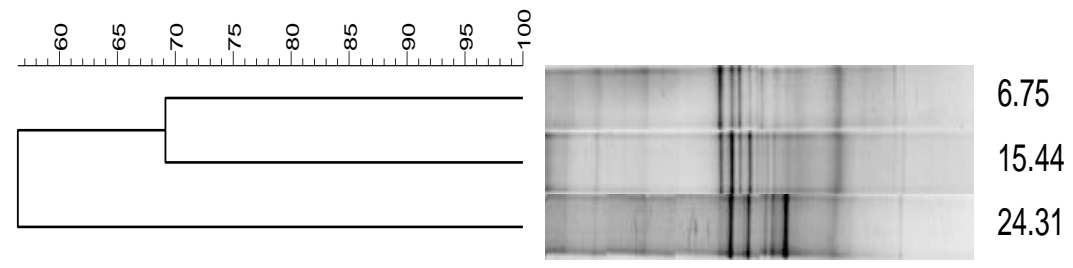

Figure 3. Dendrogram (UPMA) of the band profiles of the Bacteria and their similarity coefficient in percentage (Pearson correlation [0.0\% - 100.0\%]) for sludge blanket to VOL of $6.75 \mathrm{~kg}$ COD. $\mathrm{m}^{-3} \cdot \mathrm{d}^{-1}$ ; VOL of $15.44 \mathrm{~kg} \mathrm{COD} \cdot \mathrm{m}^{-3} \cdot \mathrm{d}^{-1}$ and VOL of $24.31 \mathrm{~kg} \mathrm{COD} \cdot \mathrm{m}^{-3} \cdot \mathrm{d}^{-1}$.

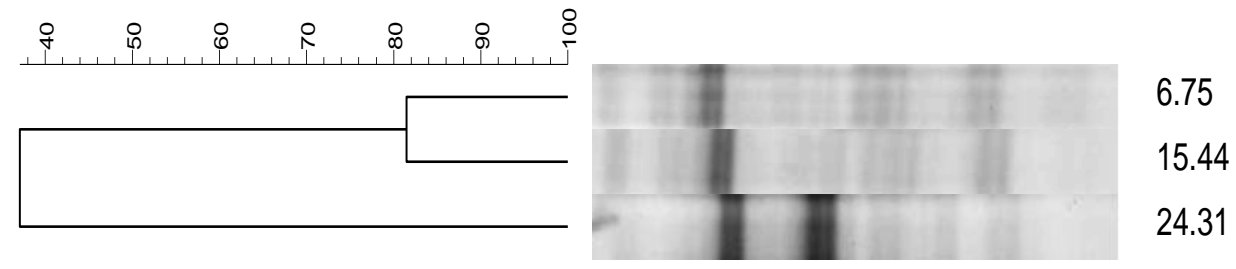

Figure 4. Dendrogram (UPMA) of the band profiles of the SRB and their similarity coefficient in percentage (Pearson correlation [0.0\% - 100.0\%]) for sludge blanket to VOL of $6.75 \mathrm{~kg} \mathrm{COD} \cdot \mathrm{m}^{-3} \cdot \mathrm{d}^{-1}$; VOL of $15.44 \mathrm{~kg} \mathrm{COD} \cdot \mathrm{m}^{-3} \cdot \mathrm{d}^{-1}$ and VOL of $24.31 \mathrm{~kg} \mathrm{COD} \cdot \mathrm{m}^{-3} \cdot \mathrm{d}^{-1}$.

\section{DISCUSSION}

The influent composition and the organic loading rate (OLR) have effects on the performance of the UASB reactor, as well as the biological composition of the granules. Specific methanogenic activity (SMA) assay characterized the methanogenic potential of the inoculum from a poultry slaughterhouse and the sludge from the UASB reactor blanket with 86 days of operation feed with vinasse. The maximum methane production rate for the inoculum was $38 \mathrm{~mL} \mathrm{CH}_{4}$ g. SSV${ }^{-1}$. $\mathrm{d}^{-1}$, indicating that the inoculum was adequate for starting the UASB reactor. For granular sludge used as inoculum "seed" in anerobic treatment 
processes, the activity rate ranging from 0.1 to $0.5 \mathrm{~g} \mathrm{CH}_{4} \mathrm{COD}$. $\mathrm{gSSV}^{-1} \cdot \mathrm{d}^{-1}$ (35-175 $\mathrm{mL}$ of $\mathrm{CH}_{4} . \mathrm{gSSV}^{-1} . \mathrm{d}^{-1}$ ) is considered suitable for starting the reactor [25]. The activity value of the sludge with 86 days of operation was $\left.134.6 \mathrm{~mL} \mathrm{CH}_{4} \cdot \mathrm{gSSV}^{-1} \cdot \mathrm{d}^{-1}\right)$. This value was higher than the activity value of the anaerobic granular sludge used as inoculum during the reactor startup.

With the reactor operating with volumetric organic load (VOL) in the range of 0.6-10.2 kgCOD. $\mathrm{m}^{-3} \cdot \mathrm{d}^{-1}$ (calculated according to equation 1 ), the removal efficiency values of the reactor $(\eta)$ ranged between 93 and $85 \%$, respectively. There was a subsequent removal efficiency decrease for loads above $15.4 \mathrm{~kg}$ COD. $\mathrm{m}^{-3} \cdot \mathrm{d}^{-1}$, reaching values between 59 and $48 \%$, when the reactor was operated with VOL close to $24.0 \mathrm{~kg} \mathrm{COD.} \mathrm{\textrm {m } ^ { - 3 }}$ . $\mathrm{d}^{-1}$ (Table 2). Chemical oxygen demand (COD) removal efficiency was $69 \%$ at an optimum organic loading rate (OLR) of $17.05 \mathrm{~kg} \mathrm{COD} . \mathrm{m}^{-3} \cdot \mathrm{d}^{-1}$ in a modified UASB reactor treating vinasses from hydrous ethanol [2]. Similar results were obtained from a UASB reactor treating raw vinasse at an optimum OLR of $12.5 \pm 2.1$ with $\eta$ of $71.2 \%$ [26].

The characterization of raw vinasse [26] is shown in Table 1, however the concentration of organic matter in the mixture was more diluted (raw vinasse with effluent of UASB reactor).

The VOL removed by the sludge blanket increased with increasing applied loads (Table 2). Despite the reduction in the COD removal efficiency of the system, the contribution of the organic load due to the dilution with the reactor effluent was partially absorbed by the microorganisms, not collapsing the reactor.

The COD removal efficiency dropped when the organic load exceeded $15 \mathrm{~kg}$ COD $\mathrm{m}^{-3} \cdot \mathrm{d}^{-1}$ due to the accumulation of fatty acid intermediates that were not removed by methanogenic organisms. During the operation of the reactor with VOL between $7 \mathrm{~kg}$ COD

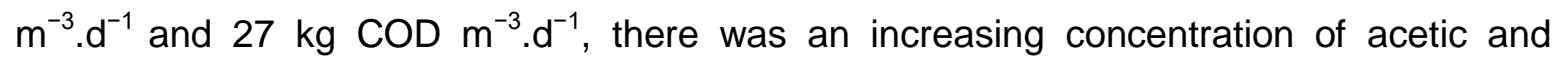
propionic acid in the effluent samples at concentrations of $580 \mathrm{mg} . \mathrm{L}^{-1}$ and $400 \mathrm{mg} . \mathrm{L}^{-1}$, respectively to VOL of $27 \mathrm{~kg}$ COD. $\mathrm{m}^{-3} \cdot \mathrm{d}^{-1}$. These same acids were the main ones found in UASB reactors fed with raw vinasse [26].

The acetic acid produced was not completely consumed by the acetoclastic methanogenic archaea and the presence of propionic acid indicates an increase in the partial $\mathrm{H}_{2}$ pressure in the system [27]. The possible reduction of the hydrogen consumption by the hydrogenotrophic methanogenic archaea contributed to the efficiency decrease of the reactor, but not reaching inhibition of the process [28]. Moreover, at such concentrations, acetic acid and propionic acid are not considered to be inhibitory to both acidogenic bacteria and methanogenic archaea [28-26].

As the propionic acid accumulated in the reactor was not directly used by the methanogenic archaea, it can be used by some sulfate reducing bacteria (SRB) producing acetic acid. Some SRB can oxidize volatile fatty acids incompletely producing acetate and also producing sulfide. Others can completely oxidize volatile fatty acids (propionic and butyric acid) to $\mathrm{CO}_{2}$ and produce sulfide during the process [29]. This microbial group is similar to methane-producing archaea (MA) in terms of the physiological and ecological aspects. SRB are more competitive with acetate and hydrogen than MA in medium with higher sulfate concentrations [30]. 
The sulfate concentration in the feed showed values varying between $1460 \pm 10$ and $1650 \pm 13 \mathrm{mg} \cdot \mathrm{L}^{-1}$ reaching removal values of $89 \%$ and $97 \%$. The sulfate concentration in the effluent samples varied between $41 \pm 3$ and $171 \pm 5 \mathrm{mg} \cdot \mathrm{L}^{-1}$. The total sulfide concentration, calculated on the basis of sulfate removal, would be in the range of $400-500 \mathrm{mg} \cdot \mathrm{L}^{-1}$. However, part of the sulfide produced was lost in the gaseous fraction of the reactor. The inhibitory sulfide levels reported in the literature are hight, in the range of $100-800 \mathrm{mg}^{-1} \mathrm{~L}^{-1}$ [2].

The main parameter controlling the interactions between SRB and AM is the relationship between the amount of organic substrates available, measured indirectly as chemical oxygen demand (COD) and sulfate concentration, [ $\left.\mathrm{SO}_{4}{ }^{2-}\right]$. During the operation of

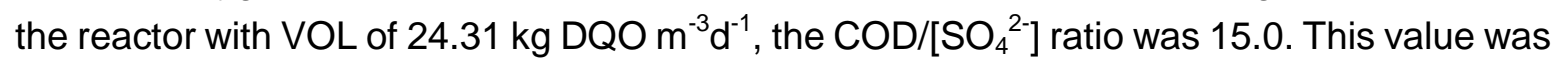
not considered inhibitory to methanogenesis in the horizontal fixed bed anaerobic reactor (HFBAR) with immobilized biomass treating sulfate-rich organic wastewater ${ }^{31}$. Theoretically, when the $\mathrm{COD} /\left[\mathrm{SO}_{4}{ }^{2-}\right]$ ratio is equal to 0.67 , there is enough sulfate for all organic matter to be consumed via sulfetogenesis[29]. In situations of $\mathrm{COD} /\left[\mathrm{SO}_{4}{ }^{2}{ }^{-}\right]$ratio above 0.67 , sulfetogenic and methanogenic processes may occur simultaneously, and below that value, sulfetogenesis may be the dominant process. Inhibition by sulfide is generally not found in anaerobic treatment, whereas the $\mathrm{COD} /\left[\mathrm{SO}_{4}{ }^{2-}\right]$ ratio in wastewater is above 10 , but inhibition is severe when the ratio is below 0.5 . This is caused by the stripping effect of high biogas production rates, which rapidly remove sulfide as it is formed at neutral $\mathrm{pH}$ [32]. The quantification of sulfate in the affluent and sulfide in the effluent, samples of the DGGE band profiles, as well as qPCR confirm the presence and activity of SRB bacteria.

The accumulation of acids associated with sulfide and enhanced by the effluent recirculation, which concentrates potentially inhibitory substances, caused a removal efficiency decrease of organic matter in the UASB under study. However, in this assay, matanogenesis and sufetogenesis occurred simultaneously.

The $\mathrm{pH}$ in the UASB reactor ranged between $7.3 \pm 0.2$ and $8.5 \pm 0.3$ and affluent alkalinity reached values between 2000 and $5500 \mathrm{mg} \mathrm{CaCO} \cdot \mathrm{L}^{-1}$. The alkalinity of the effluent remained constant in values close to $6000 \mathrm{mg} \mathrm{CaCO}_{3} \cdot \mathrm{L}^{-1}$ indicating buffer capacity and good performance of the reactor. The bicarbonate alkalinity, required to maintain stable $\mathrm{pH}$ values in a neutral-alkaline preventing unbalance of the system as the apparent volumetric organic load, increased. Moreover, the effluent recirculation in the UASB reactor was important for increasing the alkalinity of the system, promoting microbial growth and reducing preferential paths, and for improving mass transfer and decreasing the volumetric organic load variation [33].

\section{CONCLUSION}

For volumetric organic loads (VOL) in the range of $0.6 \mathrm{kgCOD} \cdot \mathrm{m}^{-3} \cdot \mathrm{d}^{-1}$ o 10 $\mathrm{kgCOD} \cdot \mathrm{m}^{-3} \cdot \mathrm{d}^{-1}$, the dilution of vinasse with reactor effluent was a positive potential strategy to treat vinasse from ethanol distillery since the removal efficiencies achieved were above $85 \%$.

The reactor operation did not have favorable results for volumetric organic loads above $24 \mathrm{kgCOD} . \mathrm{m}^{-3} \cdot \mathrm{d}^{-1}$, considering that the efficiency removal dropped below $60 \%$. Above $15 \mathrm{kgCOD} . \mathrm{m}^{-3} \cdot \mathrm{d}^{-1}$, the organic load removed did not increase with increasing VOL. 
The maintenance of the organic load removed indicates that the population developed in the reactor was adequate to maintain the process.

The real-time PCR technique was effective in the quantitative differentiation of Archaea, Bacteria and SRB, however when subjected to increasing VOL no differences were observed among the populations. The population differences were found by the DGGE technique. Thus, these molecular biology techniques are complementary, thus evaluating the importance of these organisms to stabilize the vinasse in the UASB reactor under study.

The microbial populations of the SRB were more variable with the different organic loads, however the Archaea was quantitatively higher, besides showing greater stability. The presence of SRB, together with a high sulfate removal percentage for loads of about 15 $\mathrm{kgCOD} \cdot \mathrm{m}^{-3} \cdot \mathrm{d}^{-1}$, indicates the establishment of a sulfidogenic process.

\section{REFERENCES}

1. Kaparaju P.; Serrano M.; Angelidaki, I. Optimization of biogas production from wheat straw stillage in UASB reactor. Appl. Energy 2010, 87: 3779-3783.

2. España-Gamboa E.; Mijangos C.J.O.; Hernández Z.G.; Domínguez M.J.A.; Alzate G.L.M. Methane Production by Treating Vinasses from Hydrous Ethanol using a Modified UASB reactor. Biotech. Biof 2012, 5: 1-9.

3. Christofoletti, C.A.; Escher, J.P.; Correia J.E.; Marinho, J.F.U.; Fontanetti, C.S. Sugarcane Vinasse: Environmental Implications of its use. Waste Manag 2013, 33: 2752-2761.

4. Janke, L.; Leite, A. F.; Batista, K.; Silva, W.; Nikolausz, M.; Nelles, M.; Stinne, W. Enhancing Biogas Production from Vinasse in Sugarcane Biorefineries: Effects of Urea and Trace Elements Supplementation on Process Performance and Stability. Biores Tech 2016; 217: 10-20.

5. Amorim, H.V.; Lopes, M.L.; Oliveira, J.V.C.; Buckeridge, M.S.; Goldman, G.H. Scientific Challenges of Bioethanol Production in Brazil . Appl Microb and Biotech 2011; 91:1267-1275.

6. Schink, B. Energetics of Syntrophic Cooperation in Methanogenic Degradation. Microb Molec Biol Rev 1997; 61 (2): 262-287.

7. Ayman, $\mathrm{Oz} \mathrm{N}$. Analysis of Microbial Communities Associated with Anaerobic Solvent Degradation in Sequencing Batch Reactors by Traditional and Molecular Tools. 2008.

8. Harmsen, H.J.M.; Kengen, H.M.P.; Akkermans, A.D.L.; Stams, A.J.M.; de Vos W.M. Detection and Localization of Syntrophic Propionate-Oxidizing Bacteria in Granular Sludge by In Situ Hybridization Using 16S rRNA-Based Oligonucleotide Probes. Appl. Env. Microb 1996; 62 (5): 1656-1663.

9. Del Nery V.; Pozzi E.; Damianovic, M.H.R.Z.; Domingues, M.R.; Zaiat M. Granules Characteristics in the Vertical Profile of a Full-Scale Upflow Anaerobic Sludge Blanket Reactor Treating Poultry Slaughterhouse Wastewater. Biores. Tech 2008; 99: 2018-2024.

10. Vela, F.J.; Gianotti E.P.; Foresti E.; Zaiat, M. Estimation of Substrate Effective Diffusivities in Anaerobic Bioparticles. Jour. Env.Tech 1999; 20 (11): 1163-1170.

11. APHA, AWWA, WEF. Standards Methods for the Examination of Water and Wastewater $(21 \mathrm{st}$ ed.). Washington DC: American Public Health Association/American Water Works Association/Water Environmental Federation. 2005. 
12. Adorno, T.M.A.; Hirasawa, S. J.; Varesche, A.M.B. Development and validation of two methods to quantify volatile acids (C2-C6) by GC/FID: headspace (automatic and manual) and liquid-liquid extraction (LLE). Am. Jour. Anal. Chem 2014; 5: 406-414.

13. Costa, R.B.; Camiloti, P.R.; Sabatini, C.A.; Santos, C.E.D.; Gomes, P.C.F.L.; Adorno, M.A.T. Matrix Effect Assessment of an Ion Chromatographic Method to Determine Inorganic Anions in Wastewater. Water Air Soil Pollut 2018; 212: 29.

14. Griffiths, R.I.; Witeley, A.S.; O’Donnell, A.G.; Bailey, M.J. Rapid Method for co-Extraction of DNA and RNA from Natural Environments for Analysis of Ribosomal DNA and rRNA-Based Microbial Community Composition. Appl Microb Biotech 2000; 66: 5488-5491.

15. Muyzer, G.; Waal, E.C.; Uitterlinden, A.G. Profiling of Complex Microbial Populations by Denaturing Gradient Gel Electrophoresis Analysis of Polymerase Chain Reaction-Amplified Genes Coding for 16S rRNA. Appl Environ Microbiol 1993; 59: 695-700.

16. Heid, C.A.; Junko, S.; Livak, K.J.; Williams, P.M. Real Time Quantitative PCR. Gen Res 1996; 6: 986-994.

17. Kudo Y.; Nakajima T.; Miyaki T.; Oyaizu, H. Methanogen flora of paddy soils in Japan. FEMS Microb Ecol 1997; 22: 39-48.

18. Nielsen, T.A.; Liu, W.T.; Filipe, C.; Grady, L.; Molin, S.; Stahl, D.A. Identification of a Novel Group of Bacteria in Sludge from a Deteriorated Biological Phosphorus Removal Reactor. Appl Microb Biotech 1999; 65:1251-1258.

19. Geets, J.; Borremans, B.; Diels, L.; Springael, D.; Vangronsveld, J.; van der Lelie, D.; Vanbroekhoven, K. DsrB gene-based DGGE for Community and Diversity Surveys of Sulfate-Reducing Bacteria. Jour Microb Meth 2006; 66: 194- 205.

20. Vitzthum, F.; Geiger, G.; Bisswanger, H.; Brunner, H.; Bernhagen, J.A. Quantitative Fluorescence-based Microplate Assay for the Determination of Double-Stranded DNA using SYBR Green I and a Standard Ultraviolet Transilluminator Gel Imaging System. Anal. Bioch 1999; 276: 59-64.

21. Contreras, J.P., Urritia, H; Sossa, K.; Nocker, A. Effect of PCR Amplicon length on Suppressing Signals from Membrane-Compromised cells by Propidium Monoazide Treatment. Jour Microb Meth 2011; 87(1): 89-95.

22. Casamayor, E.O.; Schafer, H.; Baneras, Li., Pedros-Alio,C.; Muyzer, G. Identification of and Spatio-Temporal Differences between Microbial Assemblages from two Neighboring Sulphurous Lakes: Comparison by Microscopy and Denaturing Gradient Gel Electrophoresis. Appl Environ Microb 2000; 66: 499-508.

23. Whelan, J.A.; Russel, N.B.; Whelan, M.A. A Method for the Absolute Quantification of cDNA using Real Time PCR. Jour Immun Meth 2003; 278: 261-269.

24. Kruskal W.; Wallis, W.A. Use of Ranks in One-Criterion Variance Analysis. Jour of the Amer Stath Assoc 1952; 47: 583-621.

25. Show, K.Y.; Wang, Y.; Foong, S.F.; Tay, J.H. Accelerated Start-up and Enhanced Granulation in Upflow Anaerobic Sludge Blanket Reactors. Wat Res 2004; 38: 2293-2304.

26. Cabrera-Díaz, A.; Oliva-Merencio, D.; Pereda-Reyes, I.; Zaiat, M. Anaerobic Digestion of Sugarcane Vinasse through a Methanogenic UASB Reactor followed by a Packed Bed Reactor. Appl Bioch Biotech 2017; 183 (4): 1127- 1145. 
27. Speece, R. E. Anaerobic Biothechnology for Industrial Wastewaters. Tennessee. Archae Press. 1996.

28. Wang. Y.; Zhang, Y.; Wang, J.; Meng, L. Effects of Volatile Fatty Acid Concentrations on Methane Yield and Methanogenic Bacteria. Biom Bioen 2009; 33: 848-853.

29. Lens, P.; Visser, A.; Jansen, A.; Hulshoff Pol, L.; Letinga G. Biotecnolgical Treatment of Sulfate-rich Wastewaters: Critical Reviews. Environ Sci Tech 1998; 28 (1): 41-88.

30. Kumar, S. Anaerobic Biotechnology for Bioenergy Production: Principles and Applications. John Wiley \& Sons, Inc. 2008.

31. Damianovic, M. H., Sakamoto, I. K., Foresti, E. Biofilm Adaptation to Sulfate Reduction in Anaerobic Immobilized Biomass Reactors Submitted to Different COD/Sulfate Ratios. Wat Sci Tech 2006; 54 (2): 119-126.

32. Wilkie, A.C.; Riedesel, K.J.; Owens, J.M. Stillage Characterization and Anaerobic Treatment of Ethanol Stillage from Conventional and Cellulosic Feedstocks. Biom Bioen 2000; 19: 63-102.

33. Lomas, J. M.; Urbano, C.; Camarero, L. M. Influence of Recirculation Flow in a Pilot Scale Downflow Stationary Fixed Film Anaerobic Reactor Treating Piggery Slurry. Biom Bioen 2000; 18 (5): $421-430$.

34. Callejas, C.; Castelló, E.; Passeggi, M.; Borzacconi, L.; Etchebehere, C.; López I. Dinámica de Comunidades Microbianas presentes en Reactores Anaerobios de Tratamientos de Aguas Residuales Industriales Nacionales: un Abordaje desde la Biología Molecular, V Encuentro Regional / XXVI Congreso Interamericano de Ingeniería Química, Montevideo, 2012.

35. Amani, T.; Nosrati, M.; Sreekrishnan, T.R. Anaerobic Digestion from the Viewpoint of Microbiological, Chemical, and Operational Aspects - A Review. Environ Rev 2010; 18: 255-278.

36. Traversi, A.; Nosrati, M.; Sreekrishnan, T.R. The Role of Different Methanogen groups Evaluated by Real-Time qPCR as High-Efficiency Bioindicators of Wet Anaerobic co-digestion of Organic Waste. AMB Express 2011; 1 - 28.

37. Song, M.; Shin, S.G.; Hwang, S. Methanogenic Population Dynamics Assessed by Real-Time Quantitative PCR in Sludge Granule in Upflow Anaerobic Sludge Blanket Treating. Bior Tech 2010; 101: 523-528.

38. van Haandel, A.; De Vrieze, J.; Verstraete, W., Santos, V.S. Methanosaeta Dominate Acetoclastic methanogenesis during High-Rate Methane Production in Anaerobic Reactors Treating Distillery Wastewaters. Jour Chem Tech Biotech 2014; 89: 1751- 1759.

39. Ribas, M.M.F.; Chinalia, F.A.; Pozzi E.; Foresti, E. Microbial Succession within an Anaerobic Sequencing Batch Biofilm Reactor (ASBBR) Treating Cane Vinasse at 55ㄷ. Braz Arch Biol Technol 2009; 52(4): 1027-1036.

40. Dar, S.A; Yao, L.; van Dongen, U. J.; Kuenen, G.; Muyzer, G. Analysis of Diversity and Activity of Sulfate-Reducing Bacterial Communities in Sulfidogenic Bioreactors using 16S rRNA and dsrB Genes as Molecular Markers. Appl Environ Microb 2007; 73 (2): 594-604.

41. Ben-Dov, E.; Brenner, A.; Ariel, K. Quantification of Sulfate-Reducing Bacteria in Industrial Wastewater, by Real-Time Polymerase Chain Reaction (PCR) using dsrA and apsA genes. Microb Ecol 2007; 54: 439- 451. 
(C) 2018 by the authors. Submitted for possible open access publication under the terms and conditions of the Creative Commons Attribution (CC BY NC) license (http://creativecommons.org/licenses/by-nc/4.0/). 